\title{
Efficacy of D,L-methadone in the treatment of glioblastoma in vitro
}

\author{
Konstantin Brawanski', Gero Brockhoff², Peter Hau ${ }^{3,4}$, Arabel Vollmann-Zwerenz ${ }^{3,4}$, \\ Christian Freyschlag ${ }^{1}$, Annette Lohmeier ${ }^{4,5}$, Markus J Riemenschneider ${ }^{4,6}$, Claudius Thomé ${ }^{1}$, \\ Alexander Brawanski ${ }^{4,5}$ \& Martin A Proescholdt*,4,5 \\ ${ }^{1}$ Department of Neurosurgery, University Hospital Innsbruck, Innsbruck, Austria \\ ${ }^{2}$ Department of Gynecology \& Obstetrics, University Hospital Regensburg, Regensburg, Germany \\ ${ }^{3}$ Department of Neurology, University Hospital Regensburg, Regensburg, Germany \\ ${ }^{4}$ Wilhelm Sander-NeuroOncology Unit, University Hospital Regensburg, Regensburg, Germany \\ ${ }^{5}$ Department of Neurosurgery, University Hospital Regensburg, Regensburg, Germany \\ ${ }^{6}$ Department of Neuropathology, University Hospital Regensburg, Regensburg, Germany \\ *Author for correspondence: Tel.: +49 941944 9051; Fax: +49 941944 9063; martin.proescholdt@ukr.de
}

Aim: Recently, D,L-methadone has been put forward as adjuvant treatment in glioblastoma (GBM). Methods: We analyzed the $\mu$-opioid receptor expression in a set of GBM cell lines and investigated the efficacy of

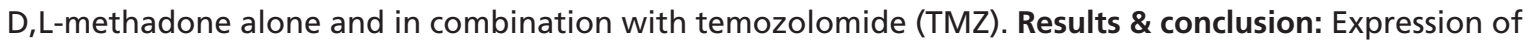
the $\mu$-opioid receptor was similar in the tested cell lines. High concentrations of $D, L$-methadone induced apoptosis in all cell lines and showed treatment interaction with TMZ. However, in lower dosages, reflecting clinically attainable concentrations, D, L-methadone alone showed no efficacy, and induced even higher proliferation in one specific cell line. Also, no interaction with TMZ was observed. These results suggest caution to the premature use of D, L-methadone in the treatment of GBM patients.

First draft submitted: 8 April 2018; Accepted for publication: 30 May 2018; Published online: 19 June 2018

Keywords: adjuvant treatment $\bullet$ glioblastoma $\bullet$ methadone $\bullet$ temozolomide

Glioblastoma multiforme (GBM) is the most frequent malignant brain tumor in adults [1,2]. Despite multimodal treatment consisting of maximal safe resection followed by radiation and chemotherapy, tumors recur with a median time to progression of approximately 7 months leading to a median survival of about 15 months $[3,4]$. In recent years, many of the molecular pathways involved in the initiation and promotion of GBM have been unraveled [5,6], yet no superior treatment strategy could be deduced from those studies. In particular, neither antiangiogenic [7] nor immune-stimulating [8] treatments have been successful in clinical studies so far. Recently, D,L-methadone has been put forward as a potential approach to improved adjuvant treatment in GBM. In fact, Friesen et al. [9] showed that D,L-methadone mediates enhanced apoptosis and increased sensitivity toward doxorubicin in established GBM cell lines by reversing deficient caspase activation and reducing intracellular cAMP levels. Furthermore, a recent retrospective report from 27 recurrent GBM patients treated with increasing D, L-methadone concentrations implies a moderate toxicity, while no efficacy data were reported due to the absence of a control arm in this study [10]. D,L-methadone is a $\mu$-opioid receptor agonist, stimulating inhibitory $\mathrm{G}_{\mathrm{i}}$-proteins, which in turn block adenylyl cyclase activity, followed by an decrease of cAMP levels [11]. cAMP acts as second messenger targeting the cAMP-dependent PKA, either inhibiting or activating the MAPK depending on the biological context of the targeted cells [12]. Consequently, the hallmark of cAMP interference is the ability to inhibit cell growth and induce apoptosis in one cell type, while enhancing cell growth and inhibiting apoptosis in another [13]. It is therefore conceivable, that individual GBM cells treated with D,L-methadone show different treatment sensitivity with respect to cell growth and survival. Although doxorubicin has great impact in the treatment of breast cancer [14], lymphoma [15] or hepatocellular carcinoma [16], it was shown to have only limited clinical efficacy in malignant gliomas [17]. Although this drug is efficacious in vitro, poor penetration of the blood-brain barrier [18] and severe neurotoxic side effects [19] prevented its implementation into the treatment portfolio for GBM. The aim of this study was to investigate the $\mu$-opioid receptor expression as the target of D,L-methadone and to validate existing 


\begin{tabular}{|c|c|c|c|c|c|c|}
\hline ID & Gender & Age & GBM type & $\begin{array}{l}\text { Transcriptional } \\
\text { subtype }\end{array}$ & $\begin{array}{l}\text { MGMT promoter } \\
\text { methylation status }\end{array}$ & IDH1 mutation status \\
\hline BTIC-7 & $f$ & 53.02 & Primary & Proneural & Unmethylated & Wild-type \\
\hline BTIC-12 & $\mathrm{m}$ & 46.82 & Primary & Mesenchymal & Unmethylated & Wild-type \\
\hline BTIC-13 & $\mathrm{m}$ & 42.38 & Primary & Mesenchymal & Unmethylated & Wild-type \\
\hline BTIC-18 & $\mathrm{m}$ & 50.01 & Primary & Proneural & Unmethylated & Wild-type \\
\hline
\end{tabular}

efficacy results of D,L-methadone reported in the previous studies utilizing a panel of patient-specimen derived, molecularly well-characterized cell lines cultured under stem cell promoting conditions (brain-tumor initiating cells; BTICs) in addition to established cell lines to account for the inherent heterogeneity of GBM cell lines. Finally, we investigated the potential interaction of D,L-methadone with temozolomide (TMZ) as a clinically relevant chemotherapy backbone.

\section{Materials \& methods}

Patient specimen derived \& established glioblastoma cell lines (BTIC)

The BTICs (BTIC-7, 12, 13 and 18) were established from resected, human glioblastoma as previously described [20] and were transcriptionally characterized according to the Verhaak classification [21]. BTIC-7 and BTIC-18 were classified as proneural; BTIC-12 and BTIC-13 as mesenchymal subtype. U87 and U251 cells were used for a comparison of BTICs with established human glioblastoma cell lines (Table 1). Experiments were approved by the local ethics committee (University of Regensburg, protocol No.05/105).

\section{Cell culture \& treatment}

U87 and U251 glioblastoma cells were grown in Dulbecco's Modified Eagle's Medium (DMEM) (Biochrom/Millipore, Berlin, Germany, \#F0415) supplemented with 10\% fetal calf serum (FCS), $50 \mathrm{U} / \mathrm{ml}$ penicillin and $50 \mathrm{mg} / \mathrm{ml}$ streptomycin (Biochrom/Millipore, \#2213) and $2 \mathrm{mM} \mathrm{L-glutamine} \mathrm{(Biochrom/Millipore,}$ \#K0283). The BTICs were cultured in RHBA-based serum-free culture media (Takara, \#Y40001) supplemented with $20 \mathrm{ng} / \mathrm{ml}$ of the mitogens EGF (Miltenyi Biotec, Bergisch Gladbach, Germany, \#130-097-751) and bFGF (Miltenyi Biotec, \#130-093-842) and $50 \mathrm{U} / \mathrm{ml}$ penicillin, and $50 \mathrm{mg} / \mathrm{ml}$ streptomycin (Biochrom/Millipore, \#2213), as described [20]. All glioblastoma cell lines were cultured in a humidified atmosphere of $5 \% \mathrm{CO}_{2}$ and $95 \%$ air. D,L-methadone hydrochloride was dissolved in sterile distilled water (Hospital Pharmacy, University Hospital Innsbruck, Austria), and applied at concentrations of $0.3,1,15,30$ and $45 \mu \mathrm{g} / \mathrm{ml}$. To investigate a potential interaction with TMZ, cells were treated with TMZ alone (Sigma Aldrich, St. Louis, MO, USA, \#T2577) dissolved in DMSO at $100 \mu \mathrm{mol} / \mathrm{l}$ or in combination with the above-mentioned concentration of D,L-methadone.

\section{Western blot}

Cells were harvested by mild trypsination, washed twice in $1 \times$ PBS and centrifugated at $100 \times g$. After cell lysis in a buffer containing $8 \mathrm{M}$ urea, $0.5 \%$ Triton $\times 100,0.1 \mathrm{M}$ DTT and $40 \mu \mathrm{l} 25 \times$ protease inhibitor cocktail (complete, Sigma-Aldrich), $50 \mu \mathrm{g}$ protein was loaded per lane on a 12\% SDS PAGE gel and transferred to nitrocellulose membranes (Amersham Pharmacia Biotech, Little Chalfont, UK) by the application of $100 \mathrm{~mA}$ for $75 \mathrm{~min}$. Unspecific binding sites were blocked with 5\% dry milk dissolved in TBS-Tween buffer. To detect the expression of $\mu$-opioid receptor, we have tested a series of different antibodies. The best signal to noise ratio was achieved using a polyclonal rabbit antihuman $\mu$-opioid receptor antibody (ABCAM, Cambridge, UK, \# 137460) at a concentration of 1:750. Immunoblots were developed with enhanced chemiluminescence kits (Amersham).

\section{Immunofluorescence staining}

Cells were grown on coverslips and fixed using freshly prepared 4\% paraformaldehyde in $0.1 \mathrm{M}$ phosphate buffer ( $\mathrm{pH}$ 6.9) for $1 \mathrm{~h}$. Cells were washed three-times in $1 \times \mathrm{PBS}$ and subsequently preincubated in a solution containing $1 \%$ normal goat serum, and $0.3 \%$ Triton X-100 to block nonspecific binding sites. Primary antibody binding was performed by incubating the cells at $4^{\circ} \mathrm{C}$ overnight to a polyclonal rabbit antihuman $\mu$-opioid receptor antibody (ABCAM, Cambridge, UK) at a concentration of 1:500 in blocking solution. Control slides were incubated in nonimmunized IgG at the identical protein concentration as the primary antibody. Specific binding of the primary 
antibody was detected by incubation in a biotinylated antirabbit secondary antibody at a concentration of 1:300 for $2 \mathrm{~h}$ at room temperature, followed by exposure to streptavidin-FITC at a concentration of 1:300 for $2 \mathrm{~h}$ at room temperature (Vector).

\section{Crystal violet assay}

Cells were seeded in $100 \mu \mathrm{l}$ DMEM (established cell lines) or in RHBA-based serum-free culture medium (BTICs) at a density of 30,000 cells/well in a 96-well dish plate. After allowing the cells to attach for $24 \mathrm{~h}$, the medium was removed and treated with different concentrations $(0.3,1,15,30$ and $45 \mu \mathrm{g} / \mathrm{ml})$ of D,L-methadone, alone or in combination with $100 \mu \mathrm{M}$ TMZ. A total of $140 \mathrm{~h}$ after treatment with different concentrations, the medium was removed and $50 \mu \mathrm{l}$ of $0.5 \%$ crystal violet staining solution was added to each well and incubated for $10 \mathrm{~min}$ at room temperature as described previously [22]. The medium was removed, and the plate was washed five-times in tap water steam. Subsequently, the plates were left to air-dry for at least $2 \mathrm{~h}$ at room temperature. For quantification of cell viability, $50 \mu \mathrm{l}$ sodium citrate was added to each well and measured at $550 \mathrm{~nm}$ with a plate reader (Varioscan, Thermo Scientific).

\section{Apoptosis FACS analysis}

Cells were seeded in $2000 \mu \mathrm{l}$ DMEM or in RHBA-based serum-free culture medium at a density of 50,000 cells/well in a 6-well dish plate. As the control for D,L-methadone treatment, untreated cells were used. As a control for the TMZ in combination with D,L-methadone, the culture medium was supplemented with equimolar concentrations of DMSO. A total of $140 \mathrm{~h}$ after treatment with different concentrations, cells were harvested by trypsination. After $3 \mathrm{~min}$, the cells were collected in culture medium to terminate the enzyme activity. Subsequently, the cells were centrifugated $\left(3 \mathrm{~min}, 100 \times g, 4^{\circ} \mathrm{C}\right)$ and washed with cold PBS. The supernatant was removed, and the cells were resuspended in $75 \mu$ l Annexin solution $(5 \mu \mathrm{l}$ Annexin V-FITC and $70 \mu$ l binding buffer; both ImmunoTools, \#31490013). After $20 \mathrm{~min}$ incubation on ice and in the dark $200 \mu \mathrm{l}$ binding buffer was added to cells. 1-2 min before flow cytometric analyses diamine-2-phenylindol (DAPI; Sigma \#D9542) was added to a final concentration of $5 \mu \mathrm{g} / \mathrm{ml}$. All flow cytometric analyses were performed using the FACSCanto-II flow cytometer (BD Biosciences) using standard optical configurations provided by the manufacturer. Briefly, Annexin-FITC and DAPI staining was detected using a $530 / 30 \mathrm{bp}$ and a $450 / 40 \mathrm{bp}$ filter, respectively. Due to independent violet and blue laser excitation ( 405 and $488 \mathrm{~nm}$, respectively) compensation was not required. The data acquisition and analysis were performed with FACSDiva software (Ver. 7.0, BD Bioscience). This assay relies on the following assumption: apoptotic cells will bind Annexin V, but still exclude DAPI for a period of 4-6 h. Thus, a read out positive for annexin $V$ but negative for DAPI was defined as specific apoptosis.

\section{Statistical analysis}

Results were expressed as mean values plus standard deviation. Differences between groups were calculated by computing one-way ANOVA followed by post hoc testing (Holm-Sidack method). Significance was defined as $\mathrm{p}<0.05$ (SigmaPlot, version 13.0; Systat Software).

\section{Results}

$\mu$-opioid receptor expression

Western blotting revealed immunoreactive bands predominantly with a molecular weight of $51 \mathrm{kDa}$ in all tested cell lines. We did not detect any significant quantitative difference in the $\mu$-opioid receptor expression between the cell lines (Figure 1A). Immunofluorescence labeling showed an intense, patchy and partly clustered staining pattern, which was predominantly associated with the plasma membrane and within cell processes (Figure 1B). This pattern was similar in all tested cell lines. Replacing the primary antibody with nonimmunized IgG at the identical protein concentration revealed very low background staining (Figure 1C). Additional control experiments omitting the primary antibody and secondary antibody also resulted in minimal background staining confirming the specificity of the staining results (data not shown).

\section{Cell viability}

Although all GBM cell lines showed a decrease of cell viability in a dose dependent fashion after treatment with higher concentration of D,L-methadone alone $(15-45 \mu \mathrm{g} / \mathrm{ml}$; Figure 2), we observed a differential susceptibility of the tested cell lines, with BTIC-7 (proneural) responding with the highest and BTIC-12 (mesenchymal) with 


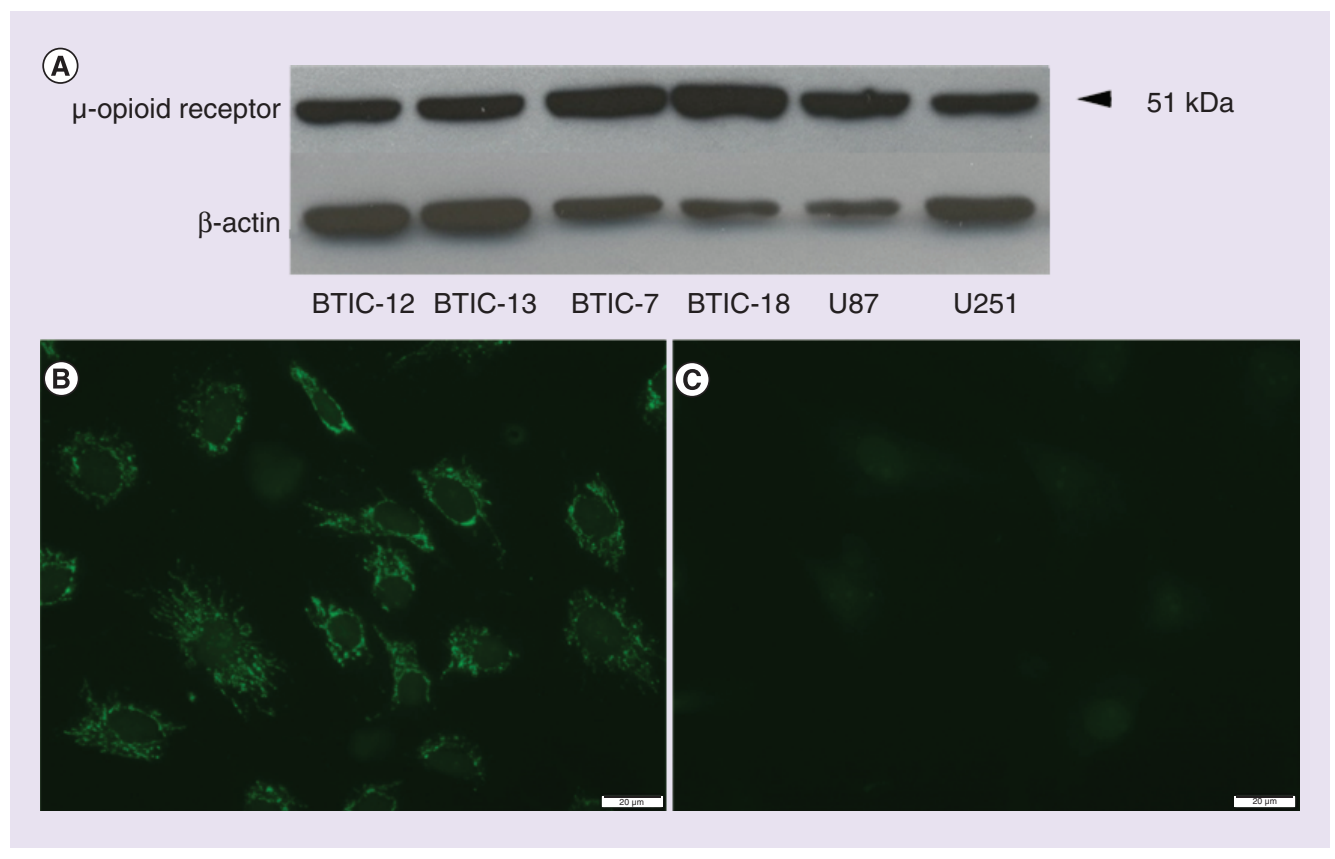

Figure 1. Expression of the $\mu$-opioid receptor in glioblastoma multiforme cells. (A) Western blotting experiments detected a protein with a molecular size of $51 \mathrm{kDa}$, which corresponds to a glycosylated form of the receptor with a predicted size of $43 \mathrm{kDa}$ [23]. No significant difference in the expression levels were detected between the tested cell lines. (B) Immunofluorescence staining of the BTIC-18 cell line revealed a clustered, patchy expression pattern, associated with the plasma membrane as well as cell processes. There was no difference in the staining results between all cell lines. (C) Application of nonimmunized rabbit IgG in control slides induced minimal background staining confirming the specificity of the antibody labeling.

BTIC: Brain tumor initiating cell.

the lowest sensitivity to D,L-methadone. At a concentration of $1 \mu \mathrm{g} / \mathrm{ml}$, we did not detect any reduction of cell viability except for $\mathrm{U} 87$, and at $0.3 \mu \mathrm{g} / \mathrm{ml}$, which corresponds to the maximal concentration which could be reached during clinically tolerable dosage, there was no induction of cell death, in fact, we even observed a significantly increased cell viability in BTIC-18 (proneural, Figure 2). Positive interaction between TMZ and D,L-methadone were observed only in higher concentrations of D,L-methadone; in BTIC-7 starting at $15 \mu \mathrm{g} / \mathrm{ml}$ (Figure 3), at $45 \mu \mathrm{g} / \mathrm{ml}$ in U251, BTIC-13 and BTIC-18 (Figure 3); BTIC-12 showed no interaction with TMZ (Figure 3). Interestingly in U87, we detected a significantly antagonistic effect of D,L-methadone to TMZ in concentrations from 1 to $30 \mu \mathrm{g} / \mathrm{ml}$ (Figure 3).

\section{Apoptosis}

The BTICs showed significant induction of apoptosis upon D,L-methadone treatment alone exclusively at concentrations of $45 \mu \mathrm{g} / \mathrm{ml}$ (Figure 4). In contrast, the established cell lines U251 and U87 showed an increased fraction of apoptotic cells when treated with concentrations starting from $1 \mu \mathrm{g} / \mathrm{ml}$ (U251) to $15 \mu \mathrm{g} / \mathrm{ml}$ (U87), respectively (Figure 4). Positive interaction with TMZ on the induction of apoptosis occurred in the BTICs exclusively in the proneural cell lines (BTIC-7 starting at $30 \mu \mathrm{g} / \mathrm{ml}$ and BTIC-18 at $45 \mu \mathrm{g} / \mathrm{ml}$; Figure 4 ) whereas in the mesenchymal cell lines (BTIC-12 and BTIC-13 Figure 4) no interaction with TMZ was observed. In contrast, the adherent cell lines U87 and U251 displayed positive interaction with TMZ starting at concentrations of 1 and $15 \mu \mathrm{g} / \mathrm{ml}$, respectively (Figure 4).

\section{Discussion}

The treatment of GBM still remains a formidable challenge. Despite significant progress in the understanding of the molecular pathogenesis no adjuvant treatment options besides radiochemotherapy have been established for this disease so far [3,4]. One reason for the dismal prognosis may be the inherent resistance to adjuvant therapy such as radiation and chemotherapy [24,25], By the search for improved treatment results, D, L-methadone has been suggested as an agent, which may sensitize tumor cells including GBM to genotoxic treatment regimen [9,26-29]. 


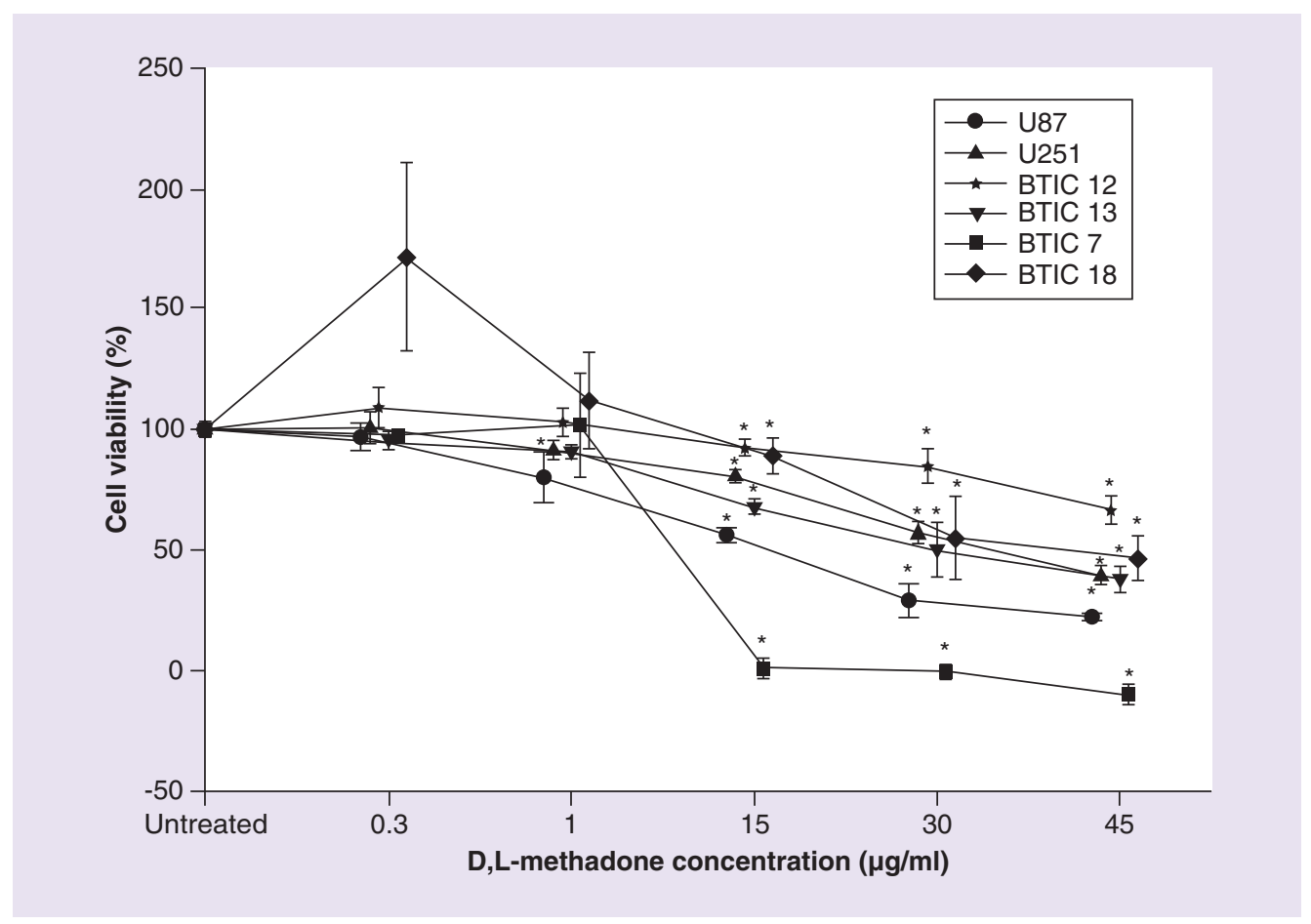

Figure 2. Effects on cell viability (in percent of untreated control) by D,L-methadone alone on all tested glioblastoma multiforme cell lines. (A) At $0.3 \mu \mathrm{g} / \mathrm{ml} \mathrm{D,L-methadone,} \mathrm{cell} \mathrm{viability} \mathrm{is} \mathrm{significantly} \mathrm{increased} \mathrm{in} \mathrm{BTIC-18.}$ (B) At concentrations of $1 \mu \mathrm{g} / \mathrm{ml}$ significant cell killing was observed only in U87. (C-E) At higher concentrations, BTIC-7 showed the highest and BTIC-12 the lowest susceptibility. The asterisk $(*)$ indicates significant differences to untreated control (significance level 0.05).

BTIC: Brain tumor initiating cell.

Due to its agonistic actions on the $\mu$-opioid receptor [30], D,L-methadone has been widely used for the treatment of cancer patients with insufficient analgesia [31]. In addition, the activation of $\mu$-opioid-receptors by D,L-methadone leads to a G-protein coupled decrease of intracellular cyclic AMP, a second messenger regulating gene transcription, cellular proliferation and apoptosis $[11,32,33]$. Previous studies reported the presence of $\mu$-opioid receptors in glioma cells [34], and demonstrated increased apoptosis in U118MG and A172 glioblastoma cell lines when treated with D,L-methadone and doxorubicin in combination [9]. However, there are several aspects which may interfere with the potentially successful application of D,L-methadone in GBM patients. First, D,L-methadone is extensively metabolized in the liver with an average half-life time of about $24 \mathrm{~h}$ [35]. For adequate efficacy in substitution therapy of opioid addicts, a daily dosage between 60 and $120 \mathrm{mg} /$ day is required. With this regimen, plasma concentrations of only $0.58 \mu \mathrm{g} / \mathrm{ml}$ were reported [36. This was confirmed by a study by Mohamad et al. reporting plasma levels between 0.15 and $0.6 \mu \mathrm{g} / \mathrm{ml}$ under maximal dosage [37]. A more recent study investigating the steadystate pharmacokinetics of (D) and (L) methadone concluded $0.251 \mathrm{ng} / \mu \mathrm{l}$ for the (L) and $0.303 \mu \mathrm{g} / \mathrm{ml}$ for the (D) enantiomer [38]. Second, as indicated by radio-labeled tracer studies, D,L-methadone shows a penetration of the blood-brain barrier of only about $42 \%$ [39,40]. Thus, with a tolerable plasma maximum of $0.6 \mu \mathrm{g} / \mathrm{ml}$ methadone, only a concentration of about $0.25 \mu \mathrm{g} / \mathrm{ml}$ could be achieved in the interstitial space of the brain. In addition, methadone is a substrate of the P-glycoprotein extrusion pump, which has been shown to be stereoselective for methadone and other compounds [41]. In GBM tissue, a significant overexpression of the P-glycoprotein efflux pump has been demonstrated and linked to the notorious resistance to systemic antitumor treatment of this disease $[42,43]$. It is therefore conceivable that the in vivo concentrations of methadone are even lower in GBM patients compared with nontumorous brain tissue, which was the subject of recent forensic studies investigating tissue concentrations of D and L methadone in the human brain [44]. A first study on the clinical feasibility of D,L-methadone in patients with recurrent GBM has used an ascending dosing protocol of D,L-methadone up to a maximum of $20-35 \mathrm{mg} /$ day [10], which is about half of the dosage used in opioid addicts. Although in this study, the observed D,L-methadone-related toxicity was rather moderate and the 6-month progression free survival 


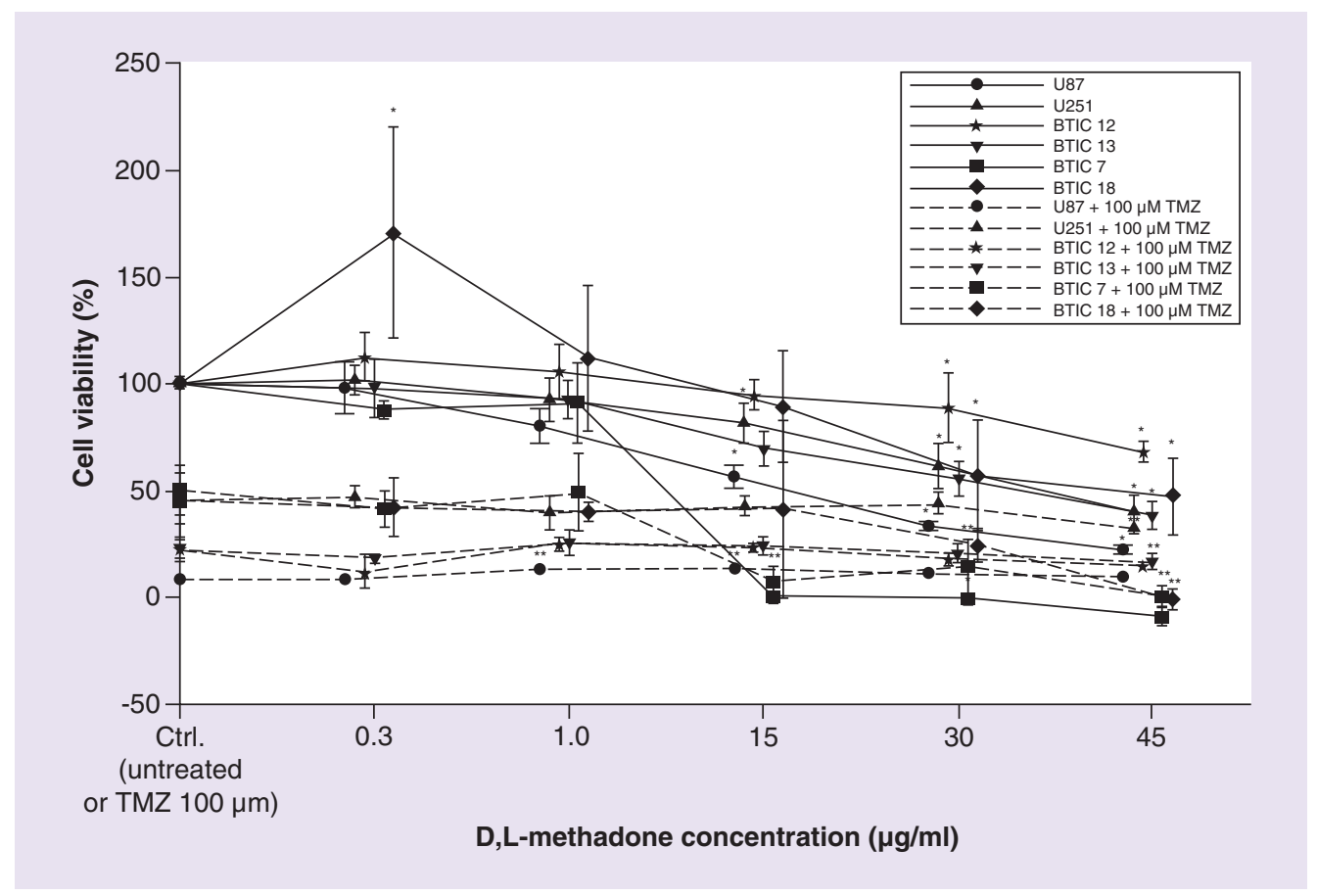

Figure 3. Interaction between D,L-methadone and temozolomide. Glioblastoma cell lines (two established, four BTICs) were treated with $0.3,1,15,30$ and $45 \mu \mathrm{g} / \mathrm{ml} \mathrm{D,L-methadone} \mathrm{alone} \mathrm{(solid} \mathrm{lines),} \mathrm{or} \mathrm{in} \mathrm{combination} \mathrm{with} \mathrm{TMZ}$ (100 $\mu \mathrm{M}$, dashed lines). After $140 \mathrm{~h}$ of treatment, cell viability was determined by crystal violet assay. The asterisk (*) indicates significant effects of D, L-methadone alone compared with the untreated control, whereas the double asterisk $(* *)$ indicates significant changes to TMZ alone (significance level 0.05 ). All experiments were repeated at least two-times.

TMZ: Temozolomide.

was found comparable to historic controls, the putative concentrations of D,L-methadone in the brain with this dose regimen are presumably significantly lower compared with the concentrations found effective in the in vitro study on GBM cells by Friesen and co-workers [9]. Third, the effects of cAMP alterations due to D,L-methadone can either be proapoptotic and antiproliferative or antiapoptotic and proproliferative. Different effects can most likely be attributed to different dosages and the biological context of the treated cell line [12,13]. Given the extensive heterogeneity of GBM [45,46], it is conceivable that D,L-methadone treatment may cause entirely unpredictable effects in the individual GBM patient, which is suggested by the data revealed in this study. In addition, the primary mode of action of D,L-methadone is still incompletely understood. For example, it remains unclear whether the $\mu$-opioid receptor is exclusively responsible for the observed effects or whether additional binding sites are required [47]. We found a significant discrepancy in the susceptibility of the tested cell lines with the proneural primary cell lines responding with highest and the mesenchymal with the lowest sensitivity. Based on the pharmacokinetic evidence outlined above, we tested a concentration of D,L-methadone of $0.3 \mu \mathrm{g} / \mathrm{ml}$, which surprisingly induced an improved cell viability in one cell line (BTIC-18, proneural). All other cell lines did not display any effects at all in this clinically relevant concentration. As for a positive interaction with TMZ, which would be a feasible chemotherapy backbone in GBM treatment, we observed significant effects of D,L-methadone only at concentrations of $15 \mu \mathrm{g} / \mathrm{ml}$ and higher, which are unlikely to be reached given the actual pharmacokinetics of D,L-methadone in the brain. In addition, the established cell line U87 displayed significantly antagonistic effects of D,L-methadone at concentrations between 1 and $30 \mu \mathrm{g} / \mathrm{ml}$. Our results regarding the $\mu$-opioid receptor expression indicated no significant difference between the tested cell lines. Thus, heterogeneity of the target expression was ruled out as a potential rationale for the discordant effects, and may not serve as a potential biomarker for a clinical efficacy of D,L-methadone. Interestingly, we found differential effects in the induction of apoptosis compared with the crystal violet testing, which is an established assay for cell viability in this context [22]. Although the established cell lines showed increased apoptosis already at lower concentrations $(1 \mu \mathrm{g} / \mathrm{ml})$, the primary cell lines became not apoptotic at all (mesenchymal subtype) or only at higher dosages (proneural subtype) which is not entirely in 


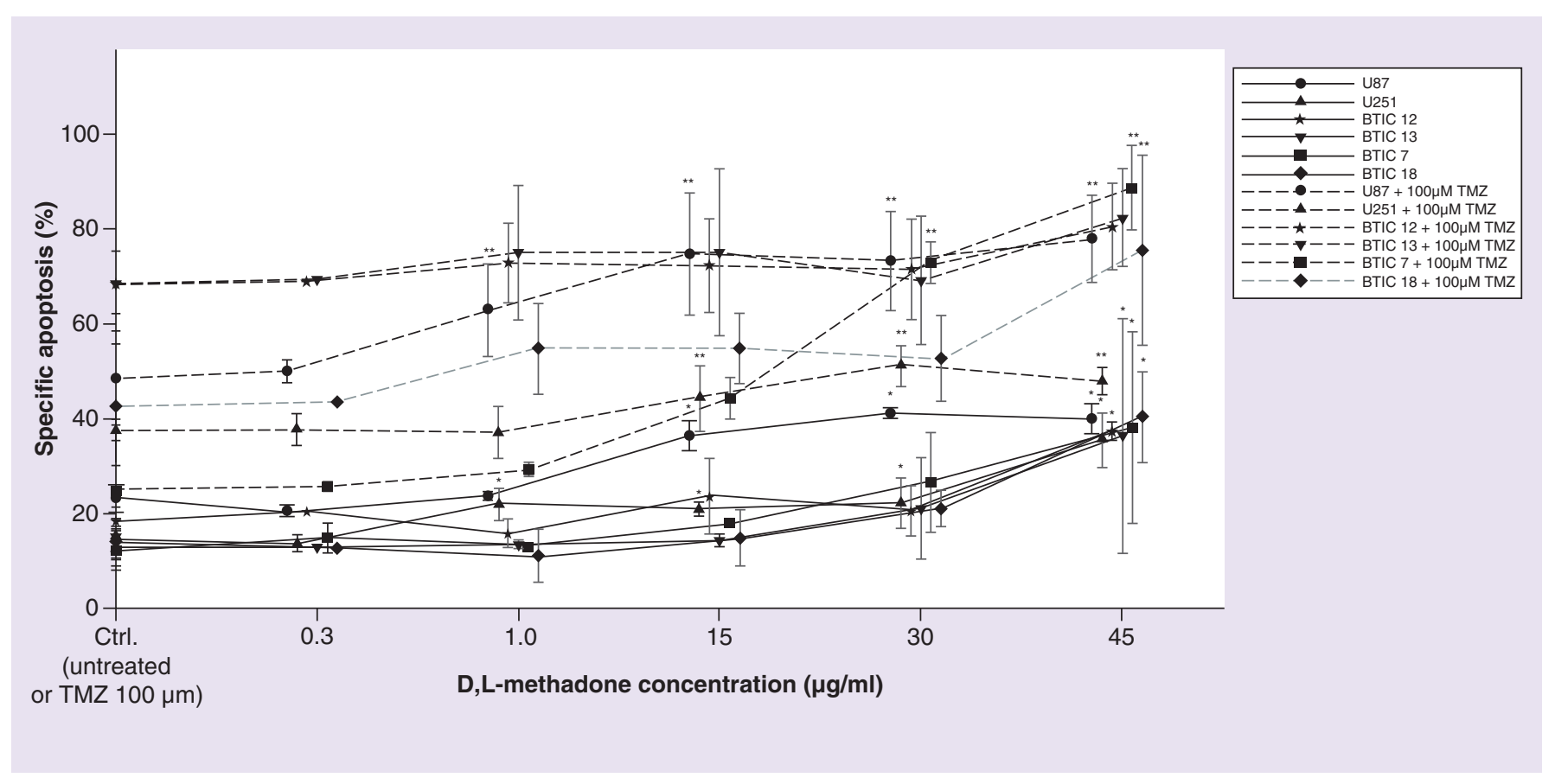

Figure 4. Induction of apoptosis detected by FACS analysis. Treatment with $0.3,1,15,30$ and $45 \mu \mathrm{g} / \mathrm{ml} \mathrm{D,L-methadone} \mathrm{alone} \mathrm{(solid}$ lines), or in combination with TMZ (100 $\mu \mathrm{M}$, dashed lines). The asterisk (*) indicates significant effects of $D, L-m e t h a d o n e$ alone compared with the untreated control, whereas the double asterisk (**) indicates significant changes to TMZ alone (significance level 0.05 ). In the BTICS, significant induction of apoptosis was observed only at high concentrations of D,L-methadone alone compared with untreated control, whereas the established cell lines showed increased rates of apoptotic cells at concentrations starting from $1 \mu \mathrm{g} / \mathrm{ml}$ (U251) to $15 \mu \mathrm{g} / \mathrm{ml}$ (U87). Interaction with TMZ occurred in the BTICs exclusively in the proneural cell lines (BTIC - 7 \& 18) at higher concentrations $(30 / 45 \mu \mathrm{g} / \mathrm{ml})$, whereas the established cell lines showed positive interaction at concentrations starting from $1 \mu \mathrm{g} / \mathrm{ml}$ (U87) to $15 \mu \mathrm{g} / \mathrm{ml}$ (U251).

BTIC: Brain tumor initiating cell; TMZ: Temozolomide.

correspondence to the cell viability assay results. It is conceivable that this phenomenon can be attributed to different primary read outs of the assays. Although the flow cytometric detection of apoptosis relies on the externalization of phosphatidylserine and the consecutive binding of annexin $\mathrm{V}[48]$ as a hallmark of apoptotic cell death, the crystal violet assay quantitatively measures bound dye to proteins and DNA [22] as a viability marker of the remaining cells. Both aspects may be influenced by a differential time series of events, which can explain the differential results in our experiments.

\section{Conclusion}

The data indicate that D,L-methadone alone or in combination with TMZ causes increased apoptosis and reduced cell viability only when applied at high concentrations which most likely will not be reached in patients with GBM. When achievable drug concentrations are used, no antitumorigenic effects of D,L-methadone could be observed in vitro. In contrast, we even detected either proproliferative or antagonistic effects to TMZ treatment in specific cell lines. Our results strongly suggest caution to the premature use of D,L-methadone in the treatment of GBM patients, and highlight the mandatory requirement of clinical efficacy studies.

Financial \& competing interests disclosure

This project was supported by the Medical Research Fund of Tirol (K Brawanski). The authors have no other relevant affiliations or financial involvement with any organization or entity with a financial interest in or financial conflict with the subject matter or materials discussed in the manuscript apart from those disclosed.

No writing assistance was utilized in the production of this manuscript. 
Summary points

- D,L-methadone, a $\mu$-opioid receptor agonist, has recently been put forward as a potential approach to improved adjuvant treatment in glioblastoma (GBM) by stimulation of inhibitory $\mathrm{G}_{i}$-proteins and reduction of adenylyl cyclase activity with subsequent decrease of intracellular cAMP levels.

- The hallmark of cAMP level reduction is its ability to induce apoptosis in one cell type and inhibit apoptosis in another, depending on the biological context of the cell.

- We therefore tested a panel of GBM cell lines, which all showed similar levels of $\mu$-opioid receptor expression, for the efficacy of $D, L$-methadone alone and the potential interactions with temozolomide (TMZ). We found a significantly different susceptibility between the cell lines with the proneural subtype showing the highest and the mesenchymal the lowest sensitivity.

- At high concentrations, D,L-methadone induced apoptosis in all cell lines; however, in dosages reflecting clinically attainable concentrations in the brain, D,L-methadone alone showed no efficacy, and induced even higher proliferation in one specific cell line. Also, at this lower dosage, we observed no interactions with TMZ; in contrast, TMZ toxicity was even antagonized in U87 cells by D,L-methadone.

- Our results suggest caution regarding the premature use of D,L-methadone in the treatment of GBM patients, and highlight the mandatory requirement of clinical efficacy studies.

Ethical conduct of research

The authors state that they have obtained appropriate institutional review board approval or have followed the principles outlined in the Declaration of Helsinki for all human or animal experimental investigations. In addition, for investigations involving human subjects, informed consent has been obtained from the participants involved.

\section{Open access}

This work is licensed under the Attribution-NonCommercial-NoDerivatives 4.0 Unported License. To view a copy of this license, visit http://creativecommons.org/licenses/by-nc-nd/4.0/

\section{References}

Papers of special note have been highlighted as: $\bullet \bullet$ of considerable interest

1. Brandes AA, Tosoni A, Franceschi E, Reni M, Gatta G, Vecht C. Glioblastoma in adults. Crit. Rev. Oncol. Hematol. 67(2), 139-152 (2008)

2. Wen PY, Kesari S. Malignant gliomas in adults. N. Engl. J. Med. 359(5), 492-507 (2008).

3. Anton K, Baehring JM, Mayer T. Glioblastoma multiforme: overview of current treatment and future perspectives. Hematol. Oncol. Clin. North Am. 26(4), 825-853 (2012).

4. Bianco J, Bastiancich C, Jankovski A, des Rieux A, Preat V, Danhier F. On glioblastoma and the search for a cure: where do we stand? Cell. Mol. Life Sci. 74(13), 2451-2466 (2017).

5. Brennan C, Momota H, Hambardzumyan D et al. Glioblastoma subclasses can be defined by activity among signal transduction pathways and associated genomic alterations. PLoS ONE 4(11), e7752 (2009).

6. Parsons DW, Jones S, Zhang X et al. An integrated genomic analysis of human glioblastoma multiforme. Science (NY) 321(5897), 1807-1812 (2008).

7. Lombardi G, Pambuku A, Bellu L et al. Effectiveness of antiangiogenic drugs in glioblastoma patients: a systematic review and meta-analysis of randomized clinical trials. Crit. Rev. Oncol. Hematol. 111, 94-102 (2017).

8. Weller M, Butowski N, Tran DD et al. Rindopepimut with temozolomide for patients with newly diagnosed, EGFRvIII-expressing glioblastoma (ACT IV): a randomised, double-blind, international Phase III trial. Lancet Oncol. 18(10), 1373-1385 (2017).

9. Friesen $\mathrm{C}$, Hormann I, Roscher $\mathrm{M}$ et al. Opioid receptor activation triggering downregulation of cAMP improves effectiveness of anti-cancer drugs in treatment of glioblastoma. Cell Cycle 13(10), 1560-1570 (2014).

10. Onken J, Friesen C, Vajkoczy P, Misch M. Safety and tolerance of D,L-methadone in combination with chemotherapy in patients with glioma. Anticancer Res. 37(3), 1227-1235 (2017).

11. Jordan B, Devi LA. Molecular mechanisms of opioid receptor signal transduction. Br. J. Anaesth. 81(1), 12-19 (1998).

12. Stork PJ, Schmitt JM. Crosstalk between cAMP and MAP kinase signaling in the regulation of cell proliferation. Trends Cell Biol. 12(6), 258-266 (2002).

13. Insel PA, Zhang L, Murray F, Yokouchi H, Zambon AC. Cyclic AMP is both a pro-apoptotic and anti-apoptotic second messenger. Acta Physiol. (Oxf.) 204(2), 277-287 (2012). 
14. Xing M, Yan F, Yu S, Shen P. Efficacy and cardiotoxicity of liposomal doxorubicin-based chemotherapy in advanced breast cancer: a meta-analysis of ten randomized controlled trials. PLoS ONE 10(7), e0133569 (2015).

15. Visani G, Isidori A. Nonpegylated liposomal doxorubicin in the treatment of B-cell non-Hodgkin's lymphoma: where we stand. Expert Rev. Anticancer Ther. 9(3), 357-363 (2009).

16. Dubbelboer IR, Lilienberg E, Ahnfelt E, Sjogren E, Axen N, Lennernas H. Treatment of intermediate stage hepatocellular carcinoma: a review of intrahepatic doxorubicin drug-delivery systems. Ther. Deliv. 5(4), 447-466 (2014).

17. Hau P, Fabel K, Baumgart U et al. Pegylated liposomal doxorubicin-efficacy in patients with recurrent high-grade glioma. Cancer 100(6), 1199-1207 (2004).

18. Neuwelt EA, Pagel M, Barnett P, Glassberg M, Frenkel EP. Pharmacology and toxicity of intracarotid adriamycin administration following osmotic blood-brain barrier modification. Cancer Res. 41(11 Pt 1), 4466-4470 (1981).

19. Merker PC, Lewis MR, Walker MD, Richardson EP, Jr. Neurotoxicity of adriamycin (doxorubicin) perfused through the cerebrospinal fluid spaces of the rhesus monkey. Toxicol. Appl. Pharmacol. 44(1), 191-205 (1978).

20. Beier D, Hau P, Proescholdt M et al. CD133(+) and CD133(-) glioblastoma-derived cancer stem cells show differential growth characteristics and molecular profiles. Cancer Res. 67(9), 4010-4015 (2007).

21. Verhaak RG, Hoadley KA, Purdom E et al. Integrated genomic analysis identifies clinically relevant subtypes of glioblastoma characterized by abnormalities in PDGFRA, IDH1, EGFR, and NF1. Cancer Cell 17(1), 98-110 (2010).

22. Feoktistova M, Geserick P, Leverkus M. Crystal violet assay for determining viability of cultured cells. Cold Spring Harb. Protoc. 2016(4), pdb prot 087379 (2016).

23. Liu-Chen LY, Chen C, Phillips CA. Beta- $[3 \mathrm{H}]$ funaltrexamine-labeled mu-opioid receptors: species variations in molecular mass and glycosylation by complex-type, N-linked oligosaccharides. Mol. Pharmacol. 44(4), 749-756 (1993).

24. Liu G, Yuan X, Zeng Z et al. Analysis of gene expression and chemoresistance of CD133+ cancer stem cells in glioblastoma. Mol Cancer 5, 67, 1-12 (2006).

25. Bao S, Wu Q, McLendon RE et al. Glioma stem cells promote radioresistance by preferential activation of the DNA damage response. Nature 444(7120), 756-760 (2006).

26. Heusch WL, Maneckjee R. Effects of bombesin on methadone-induced apoptosis of human lung cancer cells. Cancer Lett. 136(2), 177-185 (1999).

27. Friesen C, Roscher M, Alt A, Miltner E. Methadone, commonly used as maintenance medication for outpatient treatment of opioid dependence, kills leukemia cells and overcomes chemoresistance. Cancer Res. 68(15), 6059-6064 (2008).

28. Perez-Alvarez S, Iglesias-Guimarais V, Solesio ME et al. Methadone induces CAD degradation and AIF-mediated necrotic-like cell death in neuroblastoma cells. Pharmacol. Res. 63(4), 352-360 (2011).

29. Singh A, Jayanthan A, Farran A et al. Induction of apoptosis in pediatric acute lymphoblastic leukemia (ALL) cells by the therapeutic opioid methadone and effective synergy with Bcl-2 inhibition. Leuk. Res. 35(12), 1649-1657 (2011).

30. Doi S, Mori T, Uzawa N et al. Characterization of methadone as a beta-arrestin-biased mu-opioid receptor agonist. Mol. Pain 12, 1-9 (2016).

31. Parsons HA, de la Cruz M, El Osta B et al. Methadone initiation and rotation in the outpatient setting for patients with cancer pain. Cancer 116(2), 520-528 (2010).

32. Hecquet C, Lefevre G, Valtink M, Engelmann K, Mascarelli F. cAMP inhibits the proliferation of retinal pigmented epithelial cells through the inhibition of ERK1/2 in a PKA-independent manner. Oncogene 21(39), 6101-6112 (2002).

33. Kwon G, Pappan KL, Marshall CA, Schaffer JE, McDaniel ML. cAMP Dose-dependently prevents palmitate-induced apoptosis by both protein kinase A- and cAMP-guanine nucleotide exchange factor-dependent pathways in beta-cells. J. Biol. Chem. 279(10), 8938-8945 (2004).

34. Bohn LM, Belcheva MM, Coscia CJ. Evidence for kappa- and mu-opioid receptor expression in C6 glioma cells. J. Neurochem. 70(5), 1819-1825 (1998).

35. Wolff K, Hay AW, Raistrick D, Calvert R. Steady-state pharmacokinetics of methadone in opioid addicts. Eur. J. Clin. Pharmacol. 44(2), 189-194 (1993).

36. Dole VP, Kreek MJ. Methadone plasma level: sustained by a reservoir of drug in tissue. Proc. Natl Acad. Sci. USA 70(1), 10 (1973).

37. Mohamad N, Salehuddin RM, Ghazali B et al. Plasma methadone level monitoring in methadone maintenance therapy: a personalised methadone therapy. In: New Insights into Toxicity and Drug Testing. Gowder S (Ed.) InTech, Rijeka, Croatia (2013).

38. Foster DJ, Somogyi AA, Dyer KR, White JM, Bochner F. Steady-state pharmacokinetics of (R)- and (S)-methadone in methadone maintenance patients. Br. J. Clin. Pharmacol. 50(5), 427-440 (2000).

39. Oldendorf WH, Hyman S, Braun L, Oldendorf SZ. Blood-brain barrier: penetration of morphine, codeine, heroin, and methadone after carotid injection. Science (NY) 178(4064), 984-986 (1972).

40. Peters MA. Development of a 'blood-brain barrier' to methadone in the newborn rat. J. Pharmacol. Exp. Ther. 192(3), 513-520 (1975). 
41. Wang JS, Ruan Y, Taylor RM, Donovan JL, Markowitz JS, DeVane CL. Brain penetration of methadone (R)- and (S)-enantiomers is greatly increased by P-glycoprotein deficiency in the blood-brain barrier of Abcb1a gene knockout mice. Psychopharmacology (Berl). 173(1-2), 132-138 (2004).

42. Kondo $\mathrm{S}$, Kondo $\mathrm{Y}$, Hara $\mathrm{H}$ et al. $\mathrm{mdm} 2$ gene mediates the expression of $\mathrm{mdr} 1$ gene and P-glycoprotein in a human glioblastoma cell line. Br. J. Cancer 74(8), 1263-1268 (1996).

43. Leweke F, Damian MS, Schindler C, Schachenmayr W. Multidrug resistance in glioblastoma. Chemosensitivity testing and immunohistochemical demonstration of P-glycoprotein. Pathol. Res. Pract. 194(3), 149-155 (1998).

44. Holm KM, Linnet K. Determination of the unbound fraction of R- and S-methadone in human brain. Int. J. Legal Med. 130(6), 1519-1526 (2016).

45. Sottoriva A, Spiteri I, Piccirillo SG et al. Intratumor heterogeneity in human glioblastoma reflects cancer evolutionary dynamics. Proc. Natl Acad. Sci. USA 110(10), 4009-4014 (2013).

46. Patel AP, Tirosh I, Trombetta JJ et al. Single-cell RNA-seq highlights intratumoral heterogeneity in primary glioblastoma. Science (New York, N.Y.) 344(6190), 1396-1401 (2014).

47. Theile D, Mikus G. Methadone against cancer: lost in translation. Int. J. Cancer(2018). doi.org/10.1002/ijc.31356 (Epub ahead of print)

-. Recent review highlighting important clinical and molecular aspects of methadone in cancer treatment.

48. Vermes I, Haanen C, Reutelingsperger C. Flow cytometry of apoptotic cell death. J. Immunol. Methods 243(1-2), 167-190 (2000). 